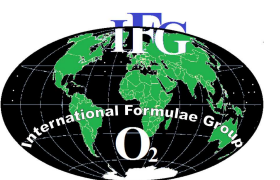

Available online at http://ajol.info/index.php/ijbcs

Int. J. Biol. Chem. Sci. 9(1): 12-23, February 2015

International Journal

of Biological and

Chemical Sciences

ISSN 1997-342X (Online), ISSN 1991-8631 (Print)

Original Paper

http://indexmedicus.afro.who.int

\title{
Infection dynamics of four gill Monogenean species from Tilapia zillii (Gervais, 1848) in man-made Lake Ayame I, Côte d'Ivoire
}

\author{
Georges KASSI BLAHOUA*, Silvain STANISLAS YAO, Raphaël N'DOUA ETILE \\ and Valentin N'DOUBA
}

\author{
Laboratory of Hydrobiology, UFR Biosciences, University of Félix Houphouët Boigny, \\ 22 P.O.Box 582 Abidjan 22, Côte d'Ivoire. \\ *Corresponding author; E-mail: kassiblahoua@yahoo.fr, Tel.: (+225) 04602531
}

\begin{abstract}
The study of the gills of 359 Tilapia zillii, which were caught between August 2004 and July 2005, have been investigated in the Ayame man-made lake (Côte d'Ivoire), so as to collect first data on the population dynamics of the Monogeneans parasites in a wild population. Standard methods of parasitological examination were used for identification of Monogenean species. Four Cichlidogyrus species were identified on the gills of host fish: C. digitatus, C. aegypticus, C. vexus and C. yanni. Rates of parasites species were calculated. Prevalence and mean intensity of the Monogenean showed clear fluctuations throughout the year. The parasites were found to settle more on the larger host fish. However, no sex effect was observed on the infestation of $T$. zillii by the Monogeneans. Throughout the period of study, all parasite species were present, because the recruitment of these organisms, although relatively low, is continuous; this logically results in their accumulation in this fish species.
\end{abstract}

(C) 2015 International Formulae Group. All rights reserved.

Keywords: Monogeneans parasitic, Tilapia zillii, population dynamics.

\section{INTRODUCTION}

Tilapia zillii (Gervais, 1848) is one of the most common fishes that is frequently caught in West African rivers (Teugels and Thys van den Audenaerde, 2003) and is a host of Monogeneans parasites, belonging to Cichlidogyrus Paperna, 1960 which usually infect Cichlids and other freshwater fishes (Pariselle and Euzet, 2009). Monogeneans are ectoparasites which can involve diseases because their development biological cycle is direct (no intermediary host) and the pathogenicity is important (El Madhi and Belghyti, 2006). Overall, fish parasites are a major component of aquatic biodiversity, and their monitoring is considered an essential element of the management of Animals health. Monogeneans that appear at low infection rates and minor pathological effects on their hosts under natural conditions can easily spread in populations confined to rearing systems, causing serious outbreaks and epizootics diseases resulting in significant economical losses (Johnson et al., 2004; Boungou et al., 2008; Velloso and Joaber, 2010). T. zillii, which is economically and ecologically important as food fish, for aquaculture, commercial aquarium trade, 
weed control and recreational fishery (Elias et al., 2014) could face such problem. This requires a good taxonomic and biological knowledge of pathogenic agents.

In tropical Africa, for a systematic revision on cichlid Monogeneans (Pariselle and Euzet, 2009), the host specificity and biological cycle (Aloo, 2002; Tombi and Bilong Bilong, 2004) of Monogeneans have been studied. Quantitative data on population dynamics of these parasites remain scarce (Bilong Bilong and Tombi, 2005; Nwani et al., 2008). In Côte d'Ivoire, there is almost no information about the dynamics of Monogeneans parasites, the only existing data are from Blahoua et al. (2009). In this respect, the composition of Tilapia zillii parasites and their prevalence and mean intensity in Ayame I Lake are of great scientific and applied interest.

The aim of this study is to investigate the existence of Monogeneans parasites on $T$. zillii in Lake Ayame I, Côte d'Ivoire. Moreover, this study is aimed at determining the changes in Cichlidogyrus species prevalence and mean intensity level depending on seasons and biotic factors such as host size and sex.

\section{MATERIALS AND METHODS \\ Study area}

Lake Ayame I is located in southeast Côte d'Ivoire $\left(5^{0} 36^{\prime} \mathrm{N} ; 3^{0} 10^{\prime} \mathrm{W}\right)$, and is the oldest hydroelectric dam in the country (Figure 1). The reservoir has a mean depth of $10 \mathrm{~m}$ and a mean area of $135 \mathrm{~km}^{2}$ (Laë, 1997). It rises in Sui (Ghana) and enters Aby lagoon (Côte d'Ivoire). The climate of the lake area in the Bia watershed is an equatorial transition zone with two rainy seasons that are separated by a short dry period, in August and September, and a more pronounced dry season from December to March. The lake is characterized by two high water level periods, from April to June and from September to November (with maximum discharge of about $500 \mathrm{~m}^{3} \mathrm{~s}^{-1}$ ). Conversely, low water level periods are registered from December to March and from July to August (with a minimal discharge of about $0.13 \mathrm{~m}^{3} \mathrm{~s}^{-1}$ ). Mean annual water surface temperature in the reservoir is $28{ }^{\circ} \mathrm{C}$ (Ouattara et al., 2007). Water surface temperature varied from 25.9 to $26.2{ }^{\circ} \mathrm{C}$ during the small rainy season and from 29.8 to $32.7^{\circ} \mathrm{C}$ in the long rainy season (Blahoua et al., 2009). The average dissolved oxygen and water transparency ranged between $2.8-15.4 \mathrm{mgl}^{-1}$ and $550-1371 \mathrm{~mm}$ respectively (Nobah et al., 2008).

\section{Host}

The tilapiine fishes contribute greatly in the economy of inland fisheries in Côte d'Ivoire (Tah et al., 2009).

A total of 359 Tilapia zillii individuals were captured from August 2004 to July 2005. All individuals hosts were grouped in four standard length (SL) classes at $50 \mathrm{~mm}$ amplitude, which are: Class I $(50 \leq \mathrm{SL}<100)$, class II $(100 \leq \mathrm{SL}<150)$, class III $(150 \leq \mathrm{SL}$ $<200)$ and class IV $(200 \leq \mathrm{SL} \leq 250)$.

\section{Fish sampling and fixing of the biological material}

Fish assemblages were sampled using two batteries of 17 gill-nets with mesh sizes vary between 8 and $90 \mathrm{~mm}$. Each net measures $30 \mathrm{~m}$ long by $1.5 \mathrm{~m}$ deep. Gill-nets were set parallel to the bank during high and low water periods. Nets were set overnight (17h-07h) and during the following day (07h$12 \mathrm{~h})$.

Once caught, the fish were immediately identified according to the keys given by Teugels and Thys van den Audenaerde (2003). Their left gill arches were isolated from bucco-pharyngeal cavity by dorsal and ventral sections and then stored in ice $\left(0{ }^{\circ} \mathrm{C}\right)$. The fish were weighed, the standard length (SL) was measured and their sex was determined post-mortem (Özer and Öztürk, 2005).

\section{Research, coloration and identification of Monogeneans}

In the laboratory, after thawing at air, the parasites were detached from the gills using strong of water current and transferred 


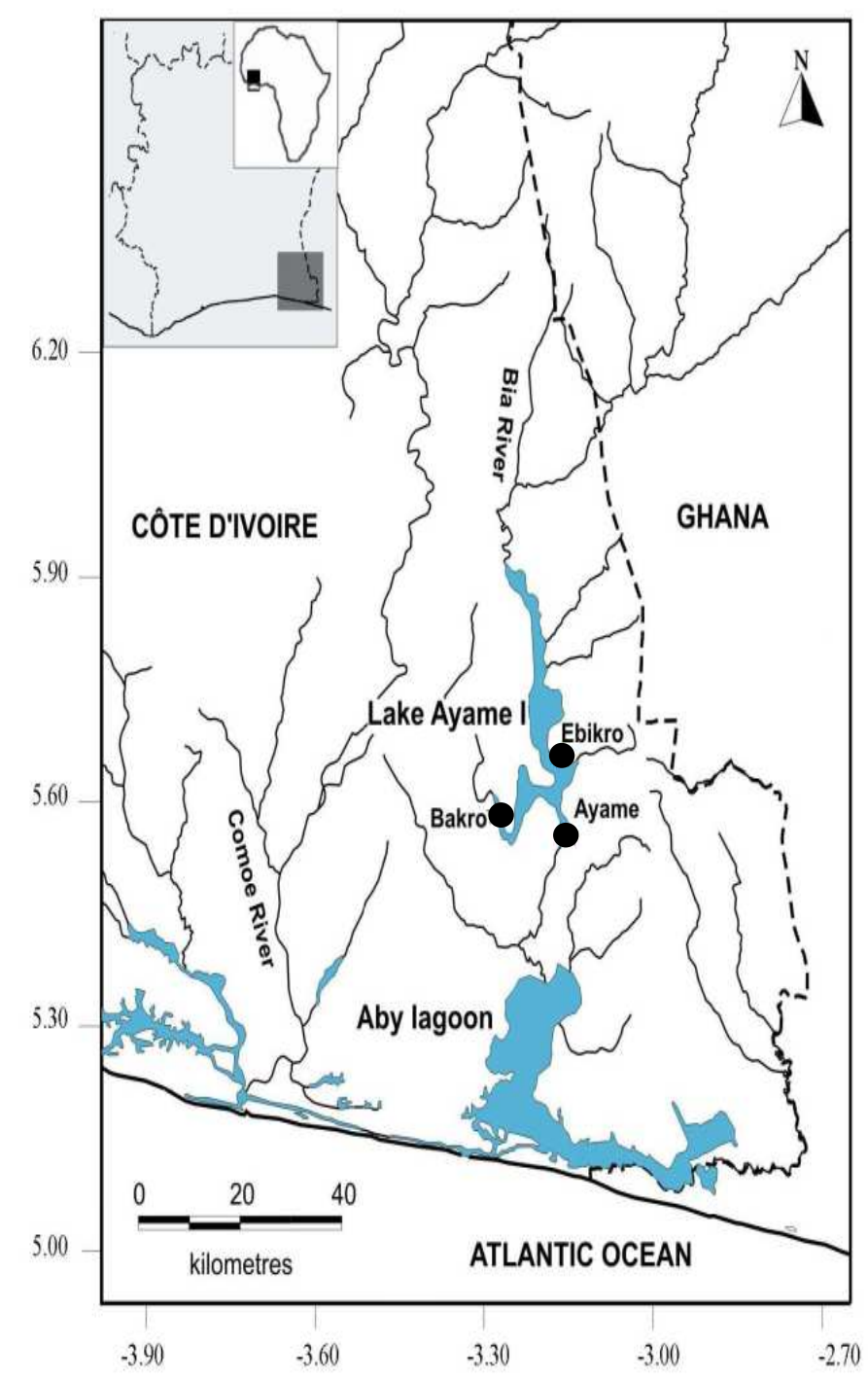

Figure 1: Geographical location of lake Ayame I (Côte d'Ivoire) and sampling sites (

individually with a needle directly into a drop of ammonium picrate-glycerine mixture (Malmberg, 1957).

The different species were identified using a microscope magnification of 400 and $1000 \mathrm{X}$ according to the keys given by Pariselle and Euzet (2009).

\section{Epidemiological approach}

The parasitism of Tilapia zillii by Monogeneans parasites in function of time, size and sex of host were studied. Relations between rates of infestation were investigated using statistical index frequently used in ecology: prevalence (proportion of the population infected) and mean intensity (mean number of parasites of infected hosts) which were calculated and applied according to Bush et al. (1997).

\section{Statistical analysis}

The Chi-square tests $\left(\chi^{2}\right)$ was applied to the data to compare the rates of infestation (prevalence). Analysis of variance and 
Student $\mathrm{U}$ test were used to determine the existence of any meaningful difference in mean intensity of the parasites species.

Statistical analysis was performed at the significance level of $5 \%$ using STATISTICA 6.0.

\section{RESULTS}

The study reveals the presence of four Monogeneans species: Cichlidogyrus digitatus Dossou, 1982, C. aegypticus Ergens, 1981, C. vexus Pariselle and Euzet, 1995 and Cichlidogyrus yanni Pariselle and Euzet, 1995 on the gills of the fish.

\section{Temporal variation of the occurrence of the parasites}

Cichlidogyrus digitatus : was present on the host population throughout the four consecutive seasons. The lowest prevalence of infestation (78.1\%) was observed in the long dry season. The highest values were recorded during the long rainy season with a rate of $100 \%$ (Table 1). The Chi-square test $\left(\chi^{2}\right)$ applied to the temporal variations of the occurrence of the $C$. digitatus showed that these values were statistically significant at $5 \%\left(\chi^{2}=43, \mathrm{df}=3\right)$. Mean intensity values ranged from 10.8 to 41.3 . Analysis of variance test was significant between seasons $(\mathrm{F}=37.2$, $p<0.05$ ). Student test also showed that there was significantly difference from one season to another except from the small to the long dry season $(p<0.05)$ (Table 1$)$.

Cichlidogyrus aegypticus : This species occurred during the sampling period. The numbers of the infected fish were overall a little lower compared to the first parasite described. They varied from $37.7 \%$ in the long dry season with a peak of $96 \%$ in the long rainy season. Moreover, the prevalence variations during the four seasons were significant $\left(\chi^{2}=112.8, \mathrm{df}=3\right)$. The highest mean intensity value was recorded in the long rainy season. Values ranged from 7.6 to 19.2 during the study and statistically significant difference was revealed between dry and rainy seasons (Analysis of variance, $\mathrm{F}=4, p<0.05$ ). There was significantly difference from one season to another except from the small to the long dry season on the one hand and from the small to the long rainy season on the other (Student test, $p<0.05$ ) (Table 1).

Cichlidogyrus vexus : The prevalence of infestation values ranged from $28.3 \%$ to $70.1 \%$. The lowest value was registered in the long dry season and the highest in the long rainy season. Statistically, significant difference was highlighted between seasons of the year $\left(\chi^{2}=56.5, \mathrm{df}=3\right)$. The highest mean intensity was recorded in the long rainy season, ranging from 4.5 to 13.6. Analysis of variance test showed a significant difference between seasons $(\mathrm{F}=8.6, p<0.05)$. Student test revealed that there was significantly difference from one season to another except from the small to the long dry season on the one hand and from the small to the long rainy season on the other (Student test, $p<0.05$ ) (Table 1).

Cichlidogyrus yanni : This parasite was identified on all the fish examined during the year of study. The number of infected fish ranged from $18.7 \%$ to $62.5 \%$, with the lowest values recorded in the long dry season and the highest in the long rainy season. The infestation showed a clear seasonal pattern that statistically verified with Chi-square test $\left(\chi^{2}=53.8, \mathrm{df}=3\right)$. The mean intensity showed the same trend as prevalence with the highest values recorded in the long rainy season. Values ranged from 3.6 to 11.9. A significant difference of seasonal infestation was found (Analysis of variance, $\mathrm{F}=4.5, p<0.05$ ). There was significantly difference from one season to another except from the small to the long dry season on the one hand and from the small to the long rainy season on the other (Student test, $p<0.05$ ) (Table 1).

\section{Occurrence of the parasites according to the sex of the host \\ Cichlidogyrus digitatus : The prevalence of} Tilapia zillii infested by $C$. digitatus was $87.7 \%$ for male fish and $92.7 \%$ for female fish. These values were not statistically significant at $5 \%\left(\chi^{2}=2.5, \mathrm{df}=1\right)$. Intensity of infection was 26 in the male and 26.8 in the 
female. Host sex no significantly affects the infection (Analysis of variance, $\mathrm{F}=0.1, p>$ 0.05) (Table 2).

Cichlidogyrus aegypticus : Prevalence and mean intensity values were $65.1 \%$ and 15.2 for male T. zillii and $69.5 \%$ and 16.1 for female fish, respectively. These values were not statistically significant at $5 \%\left(\chi^{2}=0.8\right.$, df $=1$; analysis of variance, $\mathrm{F}=0.1, p>0.05$ ) (Table 2).

Cichlidogyrus vexus : This parasite was present in $49.2 \%$ of male $T$. zillii and $50.6 \%$ of female host. Intensity of infection was 11.2 in the male and 11.5 in the female. The Chisquare test $\left(\chi^{2}\right)$ and Analysis of variance applied at the occurrence and mean intensity of this parasite, respectively, indicate no significant difference between male and female fish $\left(\chi^{2}=0.1\right.$, df $=1$; analysis of variance, $\mathrm{F}=0.7, p>0.05)$ (Table 2 ).

Cichlidogyrus yanni : We noted that the number of $T$. zillii infested by $C$. aegypticus were $36.9 \%$ and $44.5 \%$ for male and female fish, respectively. The Chi-square test $\left(\chi^{2}\right)$ applied at the occurrence of this parasite depending on the sex of its host showed that these values were not statistically significant $\left(\chi^{2}=2.1, \mathrm{df}=1\right)$. Mean intensity values were 9 and 10.3. There is no significantly difference between sexes (Analysis of variance, $\mathrm{F}=0.3, p$ $>0.05$ ) (Table 2).

\section{Influence of the host size on parasite population}

Cichlidogyrus digitatus : All classes of fish harvested and studied hosted $C$. digitatus. The highest prevalence was registered for class IV with $100 \%$. Class I possesses a lowest prevalence with $50.9 \%$. Our results showed an increase of mean intensity in the courses of generations. Values were higher for class IV with 36.5 and lower for class I with 10.6. Statistical tests showed significant difference in rates of infestation according to the classes of size $\left(\chi^{2}=119.2, \mathrm{df}=3\right.$; analysis of variance, $\mathrm{F}=38, p<0.05)$. So, larger and older fish are more infested. Student test revealed that there was significantly difference from one class of size to another except from the classes I to II $(p<0.05)$ (Table 3).

Cichlidogyrus aegypticus : The lowest prevalence values were observed for class I $(36.4 \%)$ and the highest values for class IV $(81.1 \%)$. Mean intensity values were 7.6 and 18.6 respectively. The Chi-square test $\left(\chi^{2}\right)$ and analysis of variance applied at the occurrence of this species depending on the size of $T$. zillii indicate these values are statistically significant at $5 \%\left(\chi^{2}=40.3, \mathrm{df}=3\right.$; analysis of variance, $\mathrm{F}=37.5, p<0.05)$. So, larger fish shelter more parasites individuals. There was also a significant difference from one class of size to another (Student test, $p<0.05$ ) (Table 3).

Cichlidogyrus vexus : The lowest rates of infestation (prevalence and mean intensity) were observed in fish belonging to the class I $(14.6 \%, 6.1)$ respectively. The highest values were observed in the fish of the class IV $(66.2 \%, 12.5)$. These values reveal that larger and older fish turn to be more infested $\left(\chi^{2}=\right.$ 59.1 , df $=3$; analysis of variance, $\mathrm{F}=9.4, p<$ 0.05). Student test revealed that there was significantly difference from one class of size to another except from the classes I to II on the one hand and from the classes III to IV on the other $(p<0.05)$ (Table 3$)$.

Cichlidogyrus yanni : Prevalence values increase between class I (12.7\%) and class IV $(55.4 \%)$. The mean intensity values were lower for the class I with 3.9 and higher for the class IV with 11.20. There is significant difference between classes of size $\left(\chi^{2}=48.6\right.$, $\mathrm{df}=3$; analysis of variance, $\mathrm{F}=5.5, p<0.05)$. So, larger and older fish are more parasitized. Student test revealed that there was significantly difference from one class of size to another except from the classes I to II and III on the one hand and from the classes II to III on the other $(p<0.05)$ (Table 3). 
Table 1: Seasonal variation of different species.

\begin{tabular}{|c|c|c|c|c|c|c|c|c|c|c|}
\hline Parasites species & Seasons & $\begin{array}{c}\text { Number } \\
\text { of examined } \\
\text { fish }\end{array}$ & $\begin{array}{c}\text { Prevalence } \\
(\%)\end{array}$ & $\begin{array}{c}\text { Mean intensity } \\
\pm \text { SE }\end{array}$ & $\mathbf{F}$ & $p$-value & $\begin{array}{c}\text { Comparison } \\
\text { twoby }\end{array}$ & two & $\mathbf{t}$ & $p$-value \\
\hline \multirow{6}{*}{ Cichlidogyrus digitatus } & SDS & 79 & 81 & $12.7 \pm 0.4$ & \multirow{6}{*}{37.2} & \multirow{6}{*}{$0,00 *$} & SDS-SRS & & -5.2 & $0.00 *$ \\
\hline & & & & & & & SDS-LDS & & 1.6 & 0.12 \\
\hline & SRS & 80 & 100 & $30.7 \pm 4.8$ & & & SDS-LRS & & -7.5 & $0.00 *$ \\
\hline & LDS & 95 & 78.1 & $10.8 \pm 2$ & & & SRS-LDS & & 6.3 & $0.00 *$ \\
\hline & & & & & & & SRS-LRS & & -2.3 & $0.02 *$ \\
\hline & LRS & 105 & 100 & $41.3 \pm 12.8$ & & & LDS-LRS & & -8.7 & $0.00 *$ \\
\hline \multirow{6}{*}{ Cichlidogyrus aegypticus } & SDS & 79 & 42.9 & $7.9 \pm 1.5$ & \multirow{6}{*}{4} & \multirow{6}{*}{$0,00 *$} & SDS-SRS & & -2.2 & $0.03 *$ \\
\hline & & & & & & & SDS-LDS & & 0.4 & 0.72 \\
\hline & SRS & 80 & 87.4 & $17 \pm 4.6$ & & & SDS-LRS & & -2.3 & $0.02 *$ \\
\hline & LDS & 95 & 37.7 & $7.6 \pm 2.9$ & & & SRS-LDS & & 2.5 & $0.01 *$ \\
\hline & & & & & & & SRS-LRS & & -0.4 & 0.67 \\
\hline & LRS & 105 & 96 & $19.2 \pm 6.4$ & & & LDS-LRS & & -2.6 & $0.01 *$ \\
\hline \multirow{6}{*}{ Cichlidogyrus vexus } & SDS & 79 & 31.5 & $6.1 \pm 0.6$ & \multirow{6}{*}{8.6} & \multirow{6}{*}{$0,00 *$} & SDS-SRS & & -3.8 & $0.00 *$ \\
\hline & & & & & & & SDS-LDS & & 1.1 & 0.30 \\
\hline & SRS & 80 & 66 & $13.4 \pm 1.3$ & & & SDS-LRS & & -2.9 & $0.00 *$ \\
\hline & LDS & 95 & 28.3 & $4.5 \pm 1.4$ & & & SRS-LDS & & 5.1 & $0.00 *$ \\
\hline & & & & & & & SRS-LRS & & -0.2 & 0.81 \\
\hline & LRS & 105 & 70.1 & $13.6 \pm 4.5$ & & & LDS-LRS & & -3.6 & $0.00 *$ \\
\hline \multirow{6}{*}{ Cichlidogyrus yanni } & SDS & 79 & 23.9 & $4.7 \pm 1$ & \multirow{6}{*}{4.5} & \multirow{6}{*}{$0,00 *$} & SDS-SRS & & -2.8 & $0.00 *$ \\
\hline & & & & & & & SDS-LDS & & 0.7 & 0.50 \\
\hline & SRS & 80 & 52.2 & $10.4 \pm 0.7$ & & & SDS-LRS & & -2.4 & $0.02 *$ \\
\hline & LDS & 95 & 18.7 & $3.6 \pm 1.2$ & & & SRS-LDS & & 3.1 & $0.00 *$ \\
\hline & & & & & & & SRS-LRS & & -0.9 & 0.39 \\
\hline & LRS & 105 & 62.5 & $11.9 \pm 2.8$ & & & LDS-LRS & & -2.5 & $0.01 *$ \\
\hline
\end{tabular}

$*=$ Significant level at $p<0.05 ; \mathrm{SE}=$ Standard Error; SDS = small dry season; SRS = small rainy season; LDS = long dry season; LRS = long rainy season. 
G. KASSI BLAHOUA et al. / Int. J. Biol. Chem. Sci. 9(1): 12-23, 2015

Table 2: Prevalence $(\mathrm{P})$ and mean intensity \pm SE (MI) of species parasites according to the sex of the host.

\begin{tabular}{|c|c|c|c|c|c|c|c|c|c|}
\hline \multirow[t]{2}{*}{ Sex } & \multirow[b]{2}{*}{$\begin{array}{c}\text { Number examined } \\
\text { fish }\end{array}$} & \multicolumn{2}{|c|}{ Cichlidogyrus yanni } & \multicolumn{2}{|c|}{ Cichlidogyrus vexus } & \multicolumn{2}{|c|}{ Cichlidogyrus aegypticus } & \multicolumn{2}{|c|}{ Cichlidogyrus digitatus } \\
\hline & & $\mathbf{P}(\%)$ & $\mathbf{M I} \pm \mathrm{SE}$ & $\mathbf{P}(\%)$ & $\mathrm{MI} \pm \mathrm{SE}$ & $\mathbf{P}(\%)$ & $\mathrm{MI} \pm \mathrm{SE}$ & $\mathbf{P}(\%)$ & $\mathrm{MI} \pm \mathrm{SE}$ \\
\hline Male & 195 & 36.9 & $9 \pm 0.3$ & 49.2 & $11.2 \pm 0.3$ & 65.1 & $15.2 \pm 1$ & 87.7 & $26 \pm 0.1$ \\
\hline Female & 164 & 44.5 & $10.3 \pm 0.6$ & 50.6 & $11.5 \pm 1.4$ & 69.5 & $16 \pm 1.6$ & 92.7 & $26.8 \pm 0.8$ \\
\hline
\end{tabular}

Table 3: Prevalence $(\mathrm{P})$ and mean intensity $\pm \mathrm{SE}$ of species parasites according to the size of the host.

\begin{tabular}{|c|c|c|c|c|c|c|c|c|c|}
\hline Parasites species & $\begin{array}{c}\text { Host length } \\
\text { classe }\end{array}$ & $\begin{array}{c}\text { Number } \\
\text { of examined } \\
\text { fish }\end{array}$ & $\begin{array}{c}\text { Prevalence } \\
(\%)\end{array}$ & $\begin{array}{c}\text { Mean } \\
\text { intensity } \\
\pm \mathrm{SE} \\
\end{array}$ & $\mathbf{F}$ & $p$-value & $\begin{array}{c}\text { Comparison } \\
\text { two by two }\end{array}$ & $\mathbf{t}$ & $p$-value \\
\hline \multirow{6}{*}{ Cichlidogyrus digitatus } & class I & 55 & 50.9 & $10.6 \pm 2.8$ & \multirow{6}{*}{38} & \multirow{6}{*}{$0.00^{*}$} & classes I- II & -0.0 & 0.99 \\
\hline & & & & & & & classes I-III & -4 & $0.00 *$ \\
\hline & class II & 73 & 87.7 & $11.4 \pm 13.4$ & & & classes I- IV & -6.8 & $0.00 *$ \\
\hline & class III & 83 & 100 & $25.3 \pm 25$ & & & classes II-III & -5.5 & $0.00 *$ \\
\hline & & & & & & & classes II- IV & -9.7 & $0.00 *$ \\
\hline & class IV & 148 & 100 & $36.5 \pm 38.7$ & & & classes III- IV & -3.3 & $0.00 *$ \\
\hline \multirow{6}{*}{ Cichlidogyrus aegypticus } & class I & 55 & 36.4 & $7.6 \pm 7.7$ & \multirow{6}{*}{37.5} & \multirow{6}{*}{$0.00^{*}$} & classes I- II & -2.4 & $0.04 *$ \\
\hline & & & & & & & classes I-III & -4.6 & $0.00 *$ \\
\hline & class II & 73 & 57.5 & $7.6 \pm 4.4$ & & & classes I- IV & -8 & $0.00 *$ \\
\hline & class III & 83 & 71.1 & $17.9 \pm 26$ & & & classes II-III & -4.7 & $0.00 *$ \\
\hline & & & & & & & classes II- IV & -9.3 & $0.00 *$ \\
\hline & class IV & 148 & 81.1 & $18.6 \pm 20.7$ & & & classes III- IV & -3.4 & $0.00 *$ \\
\hline
\end{tabular}


G. KASSI BLAHOUA et al. / Int. J. Biol. Chem. Sci. 9(1): 12-23, 2015

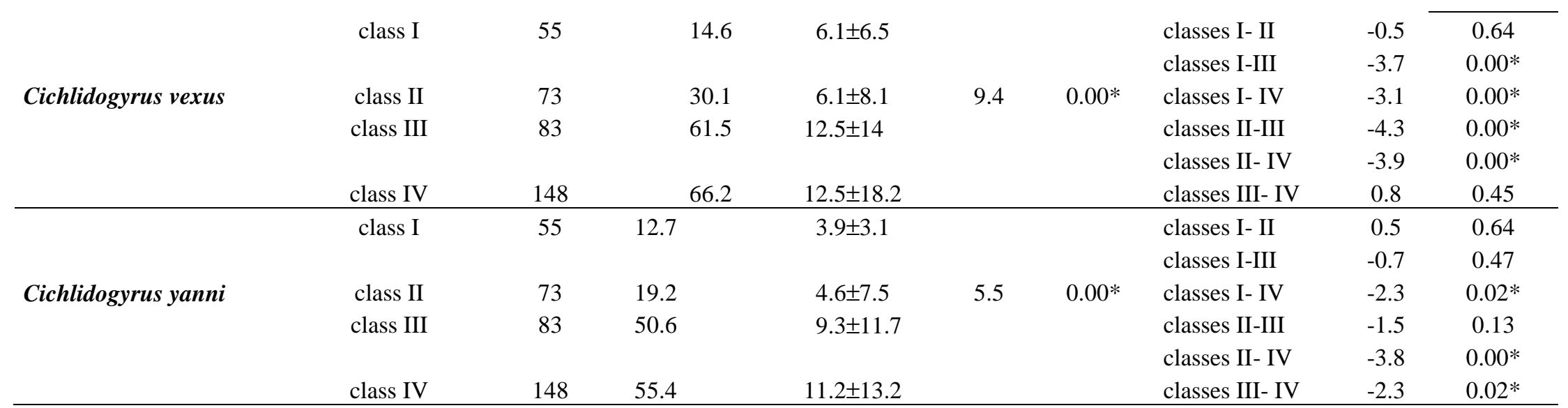

* = Significant level at $p<0.05 ; \mathrm{SE}=$ Standard Error. 


\section{DISCUSSION}

In the present study on Monogeneans gill parasites of Tilapia zillii, four species belonging to Cichlidogyrus were collected. All parasites were present throughout the sampling period. Thus, this host is vulnerable at any period. Similar data have already been reported. Indeed, in Cameroon, Bilong Bilong and Tombi (2005) observed that, except Dactylogyrus maillardi Birgi \& Lambert, 1987 which was not seen in July, there is a continuous presence of Monogenean on Barbus martorelli Roman, 1971 in Foulou stream, under-affluent of the Sanaga river. Similarly, Boungou et al. (2008) did not notice any temporary disappearance of Oreochromis niloticus Linné, 1757 Monogenean gill parasites in the dam of Loumbila, except for Cichlidogyrus rognoni Paperna, 1964 which was absent during the months of February, March, July, August, September, November and January.

The simultaneous infections of a host fish by several species have been previously reported (Buchmann and Lindenstrom, 2002; Nack et al., 2010; Ibrahim, 2012). As thought by the authors cited above, our results can be explained by the fact that in natural environment, the parasitic densities are generally low and therefore, the niches are always available on the gill biotope, thereby facilitating the simultaneous colonization of the same host by several species of Monogeneans.

This study demonstrates that the transmission of Monogeneans gill parasites in Tilapia zillii studied is seasonal, with invasion maximized during the long rainy season of the year and low infection over the long dry season. Similar results were obtained in the Foulou stream (Cameroon) by Bilong Bilong and Tombi (2005), who pointed out that the highest intensities of Barbus martorelli Monogenean gill parasites infection occurred during the long rainy season and the lowest one in the dry seasons. Moreover, the same trend was also reported by Blahoua et al. (2009) who showed that infection intensity of
Monogenean gill parasites from black-chinned tilapia (Sarotherodon melanotheron) peaked during the long rainy season. They explained this by the fact that the dry seasons were characterised by the mortality of adult worms due to of higher water temperature. According to Antonelli and Marchand (2012), temperature which generates a definite seasonal cycle, has a great influence on the population dynamics of parasites. Thus the decrease of parasites abundance in fish in Lake Ayame I might also be regarded as a temperature effect. Variation in number of parasites might be also due to the other abiotic factors such as changes in concentration of suspended solids, conductivity and water transparency which have been suggested by Blahoua (2013).

We found significant relationships between the parasite load and some hostrelated factors. Rates of infestation and intensity showed significant changes with the host fish sizes. Larger hosts harbored more parasite burden than smaller ones. This finding is in consistency with those of Morand et al. (2002), Tombi and Bilong Bilong (2004), Ibrahim (2012) and Antonelli and Marchand (2012) who found out a positive correlation between the parasitic abundances or intensities with the size of the fish. A higher parasitic level in larger fish has also been observed by Tombi et al. (2014) for the Nile tilapia (Oreochromis niloticus). These authors explained their observation by the fact that as soon as the fish grows up, the gill surface enlarges. Indeed, an increase in the branchial surface can provide a larger area of infestation, and thus more potential sites for attachment of these parasites (El Madhi and Belghyti, 2006). Lo and Morand (2001) and Simkova et al. (2006) also think that since in big fishes the volume of water passing through the gill chamber is higher, the number of oncomiricidia might also be high. However, Turgut et al. (2012) showed no significant difference in the rate of parasitism with Monogenean according to the class of size of Cyprinids fishes. On the contrary, 
Öztürk and Altunel (2006) reported that the abundance of Dactylogyrus difformis Wagener, 1857 infection was higher in younger than in older fish. This finding might be attributed to the immune response which acts in the regulation of the size of Monogenean parasite populations in older fish (Bakke et al., 2002).

As regarding the relationship between the level of Monogeneans parasites infection and the sex of host fish, there have been several researches indicating that the abundance of Monogenean is often higher on female than on the male fish (Simkova et al., 2005; Ibrahim and Soliman, 2011; Siddiqui, 2014). Ibrahim (2012) also agreed with them, reporting positive correlation between the prevalence and intensity of Monogenean and sex of the host, Tilapia zillii. However, Aloo et al. (2002) reported that males tended to harbor more parasites than females in many freshwater fish species. On the contrary, some researchers have demonstrated no relationship between parasite intensity and host sex (Tombi and Bilong Bilong, 2004; Boungou et al., 2008; Blahoua et al., 2009). The present research is in parallel with this conclusion regarding four species, Cichlidogyrus digitatus, C. aegypticus, C. vexus and $C$. yanni.

\section{ACKNOWLEDGEMENTS}

Authors wish to express their sincere thanks to the staff of Hydrobiology Laboratory of the Felix Houphouët Boigny University (Côte d'Ivoire) for fieldwork assistance, and to the Ministery of Animal Resources and Fisheries Productions of Côte d'Ivoire for providing financial support. Also thanks to Professor Bilong Bilong Charles Felix and his assistant for their critical reading of the manuscript.

\section{REFERENCES}

Aloo PA. 2002. A comparative study of helminth parasites from the fish Tilapia zillii and Oreochromis leucostictus in lake Naivasha and Oloidien bay, Kenya. J. Helminthol., 76: 95-102.

Antonelli L, Marchand B. 2012. Metazoan Parasites of the European Sea Bass Dicentrarchus labrax (Linnaeus, 1758) (Pisces: Teleostei) from Corsica. Health Environ. Aquac., 2012: 43-62.

Bakke TA, Harris PD, Cable J. 2002. Hostspecificity dynamics: observations on gyrodactylid monogeneans. Int. J. Parasitol., 32(3): 281-308.

Bilong Bilong CF, Tombi J. 2005. Temporal structure of a component community gill parasites of Barbus martorelli (Roman) (freshwater Cyprinidae) in the Centre province, Cameroon. Cam. J. Biochem. Soc., 13(1): 9-18.

Blahoua KG. 2013. Diversité biologique et dynamique des populations de Monogènes parasites branchiaux des poissons d'eaux douces: cas des Monogènes des Cichlidae, Hepsetidae, Mormyridae et des Mochokidae du lac de barrage d'Ayamé I et de la rivière Lobo (Côte d'Ivoire). Thèse Unique de Doctorat. Université Félix Houphouët Boigny, p. 187.

Blahoua KG, N'Douba V, Koné T, Kouassi NJ. 2009. Variations saisonnières des indices épidémiologiques de trois Monogènes parasites de Sarotherodon melanotheron (Pisces : Cichlidae) dans le lac d'Ayamé I (Côte d'Ivoire). Sciences et Nature, 6(1): 39-47.

Boungou M, Kabré GB, Marques A, Sawadogo L. 2008. Dynamics of population of five parasitic Monogeneans of Oreochromis niloticus Linné, 1757 in the dam of Loumbila and possible interest in intensive pisciculture. Pak. J. Biol. Sci., 11(10): 1317-1323.

Buchmann K, Lindenstrom T. 2002. Interactions between monogenean parasites and their fish hosts. Int. J. Parasitol., 32: 309-319. 
Bush AO, Kevin DL, Jeffrey ML, Allen WS. 1997. Parasitology meets ecology on its own terms. J. Parasitol., 83: 575-583.

El Madhi Y, Belghyti D. 2006. Distribution de deux Monogènes dans les individus hôtes de Trachinotus ovatus de la côte de Mehdia. Biologie et Santé, 6(2): 6576.

Elias D, Negesse K, Solomon S, Kassaye B. 2014. Food and Feeding Habits of the Red-belly Tilapia zillii (Gervais, 1848) (Pisces: Cichlidae) in Lake Ziway, Ethiopia. Agric. For. Fish, 3(1): 17-23.

Ibrahim MM. 2012. Variation in parasite infracommunies of Tilapia zillii in relation to some biotic and abiotic factors. Int. J. Zool. Res., 8(2): 59-70.

Ibrahim MM, Soliman MF. 2011. Prevalence and site preferences of heterophyid metacercariae in Tilapia zillii from Ismalia fresh water canal, Egypt. Parasite, 17: 233-239.

Johnson SC, Treasurer JW, Bravo S, Nagasawa K, Kabata Z. 2004. A review of the impact of parasitic Copepods on marine aquaculture. Zool. Stud., 43(2): 229-243.

Laë R. 1997. Estimation des rendements de pêche des lacs africains au moyen de modèles empiriques. Aquat. Living Resour., 10: 83-92.

Lo CM, Morand S. 2001. Gill parasites of Cephalopholis argus (Teleostei: Serranidae) from Moorea (French Polynesia): site selection and coexistence. Folia Parasitol., 48: 30-36.

Malmberg G. 1957. On the occurrence of Gyrodactylus on Swedish fishes. Swedish, With Description of Species and a Summary in English. Skrifterutgivna av Sodra Sveriges Fiskeriforening, 1957: 19-76.

Morand S, Simkova A, Matejusova I, Plaisance L, Verneau O, Desdevises Y. 2002. Investigating patterns may reveal processes: Evolutionary ecology of ectoparasitic monogeneans. Int. J. Parasitol., 32: 111-119.
Nack J, Tombi J, Bitja NA, Bilong Bilong CF. 2010. Sites de fixation de deux Monogènes Dactylogyridea parasites branchiaux de Clarias camerunensis : évidence sur le mode d'infestation par les Monopisthocotylea. J. Appl. Biosci., 33: 2076-2083.

Nobah KSC, Koné T, Ouattara NI, Kouamélan EP, N'Douba V, Snoeks J. 2008. Etude des performances de croissance de deux tiapias (Tilapia zillii et $T$. guineensis) et de leurs hybrides en cage flottante. Cybium, 32(2): 131-136.

Nwani CD, Oti EE, Odoh GE, Ezenwaji HMG. 2008. Endo-parasitic helminthes of four Mormyrid species (Osteichthyes : Mormyridae) from a west African flood river system. Pak. J. Biol. Sci., 11(2): 202-207.

Ouattara A, Gourène G, Podoor N. 2007. Activité photosynthétique du phytoplancton dans le barrage hydroélectrique d'Ayamé I (Côte d'Ivoire). Agronomie Africaine, 19: 6370.

Özer A, Öztürk T. 2005. Dactylogyrus cornu Linstow, 1878 (Monogena) infestation on Vimba (Vimba vimba tenella (Nordmann, 1840) caught in the Sinop region of Turkey in relation to the host factors. Turk. J. Vet. Anim. Sci., 29: 1119-1123.

Öztürk MO, Altunel FN. 2006. Occurrence of Dactylogyrus infection linked to seasonal changes and host fish size on four cyprinid fishes in lake Manyas, Turkey. Acta Zool. Acad. Sci. Hung., 52(4): 407-415.

Pariselle A, Euzet L. 2009. Systematic revision of dactylogyridean parasites (Monogenea) from cichlid fishes in Africa, the Levant and Madagascar. Zoosystema, 31(4): 849-898.

Siddiqui AA. 2014. Effects of Seasons, host age, size and sex on Monogenetic Trematode, Hamatopeduncularia indicus of host Fish, Arius jella. J. Chem. Bio. Phy. Sci., 4(2): 1146-1151. 
Simkova A, Jarkovsky J, Koubkova B, Barus V, Prokes M. 2005. Associations between fish reproductive cycle and the dynamics of metazoan parasite infection. Parasitol. Res., 95: 65-72.

Simkova A, Verneau O, Gelnar M, Morand S. 2006. Specificity and specialization of congeneric Monogenans parasiting Cyprinid. Evolution, 60: 1023-1037.

Tah L, Da Costa KS, N'Douba V, Kouassi NJ, Moreau J. 2009. Preliminary assessment of major tilapiine fishes exploited by artisanal gillnet fishery in Lake Ayame I (Bia bassin, Côte d'Ivoire). J. Fish. Int., 4(4): 83-90.

Teugels GG, Thys van den Audenaerde DFE. 2003. Cichlidae. In Faune des Poissons d'Eaux Douces et Saumâtres de l'Afrique de l'Ouest (Tome 2), Lévêque C, Paugy D, Teugels GG (eds). Musée Royal d'Afrique Centrale; Tervuren, ORSTOM : Paris; 521-600.

Tombi J, Bilong Bilong CF. 2004. Distribution of gill parasites of the freshwater fish Barbus martorelli Roman, 1971 (Teleostei: Cyprinidae) and tendency to inverse intensity evolution between Myxosporidia and Monogenea as a function of the host age. Rev. Elev. Med. Vet. Pays Trop., 57: 7176.

Tombi J, Akoumba JF, Bilong Bilong CF. 2014. The monogenean community on the gills Oreochromis niloticus from Melen fish station in Yaounde, Cameroon. Int. J. Mod. Biol. Res., 2: 1623.

Turgut EN, Develi N, Özgül G. 2012. Occurrence of Dactylogyrus species (Plathelminths, Monogenean) on Cyprinids in Almus Dam Lake, Turkey. Turk. J. Fish Aquat. Sci., 12: 15-21.

Velloso AL, Joaber PJ. 2010. Influence of ectoparasitism on the welfare of Micropogonias furnieri. Aquaculture, 310: 43-46. 